\title{
Changes in Psych-verbs: A reanalysis of little v
}

\author{
Elly van Gelderen
}

Arizona State University. Department of English

ellyvangelderen@asu.edu

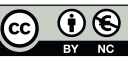

Received: July 2, 2014

Accepted: September 22, 2014

\begin{abstract}
The present paper examines psych-verbs in the history of English. As is well-known, object experiencers are reanalyzed as subject experiencers in many of the modern European languages. I discuss one such change in detail, namely the change in the verb fear from meaning 'to frighten, cause to fear' to meaning 'to fear'. The reason for the change may be the loss of the morphologically overt causative and a change in the set of light verbs. Object experiencers are constantly lost but I show there is also a continual renewal through external borrowing and internal change from physical to mental impact. A last change I discuss is the one where Subject Experiencers are reanalyzed as Agents in a $\mathrm{V}($ oice $) \mathrm{P}$.
\end{abstract}

Keywords: $p s y c h$-verb; experiencer; agent; causative; reanalysis; little v.

Resum. Canvis en els verbs psicològics: una reanàlisi de $\mathrm{v}$

Aquest article estudia els verbs psicològics en la història de l'anglès. Com és ben sabut, moltes de les llengües modernes reanalitzen els objectes experimentadors com a subjectes experimentadors. Analitzo un d'aquests canvis en detall: el canvi en el verb fear des del seu significat original d' 'espantar, fer por' al de 'témer'. El motiu del canvi podria ser la desaparició de la marca morfològica del causatiu i un canvi en el conjunt dels verbs lleugers. Encara que els objectes experimentadors es perden de manera constant, mostro que alhora hi ha una renovació incessant a través dels manlleus i mitjançant canvis interns des de sentits d'impacte físic a sentits d'impacte mental. Finalment, analitzo un canvi en què els subjectes experimentadors es reanalitzen com a agents en un Sintagma Veu.

Mots clau: verb psicològic; experimentador; agent; causatiu; reanàlisi, $v$.

\section{Table of Contents}

1. Introduction 4. Renewal of experiencer object verbs

2. Experiencer verbs in Old English: the reanalysis of object experiencers

3. The verb foran/fear
5. From experiencer to agent

6. Conclusion

References 


\section{Introduction}

Psych-verbs express mental states and involve the inclusion of an experiencer argument. Frighten and fear are psych-verbs because they need an experiencer argument. In the case of frighten, this experiencer is an object, as shown in (1a), and in the case of fear, it is a subject, shown in (1b)
(1) a. That alien frightens him.
him=object experiencer
b. He fears that alien.
he=subject experiencer

Alternations such as in (1) have been very influential for theories and formulations of theta-marking. How can verbs such as frighten have experiencer theta-roles that function as grammatical objects in (1a) whereas verbs such as fear have experiencers that function as grammatical subjects in (1b)? According to the UTAH, formulated in (2), identical thematic relations should have similar structural positions.

(2) Uniformity of Theta Assignment Hypothesis (UTAH)

Identical thematic relationships between items are represented by identical structural relationships between those items at the level of D-Structure. (from Baker 1988: 46)

Belletti and Rizzi (1988) and Pesetsky (1995), to name but a few, have proposed (generative) accounts whereby the alternation in (1) obeys the UTAH in (2). Pesetsky, in particular, has argued that that alien is a cause in (1a) but subject matter (or theme) in (1b). If we then formulate a Thematic Hierarchy, as in (3) from Pesetsky (1995), experiencers are higher than subject matter but lower than cause.

\section{(3) Thematic Hierarchy Agent $>$ Cause $>$ Experiencer $>$ Theme/Subject Matter}

The higher an argument is on the Thematic Hierarchy, the higher it is in the tree and the earlier it is pronounced. This then accounts for the order of arguments in (1).

An analysis using the notion of cause in (1a) makes sense in the light of Croft (1993) who shows that, in many languages (e.g. Lakhota and Classical Nahuatl), experiencer object verbs are marked with a causative affix. In this paper, I follow Arad (1998), Folli and Harley (2005), Pylkkänen (2008) and others who have suggested that little $v$ can have different flavors, e.g. cause or state. I chronicle what happens to little $v$ diachronically where $p s y c h$-verbs are concerned. Arad's (1998) proposal, based on Ruwet (1972) and Bouchard (1995), has perhaps been the most influential for the psych-verbs. Bouchard and Arad argue that any argument can be an experiencer and that the differences in types of $p s y c h$-verbs are due to aspectual properties. I will use $v$ and $\mathrm{V}$ heads for aspectual information.

There are many verbs with experiencer arguments, e.g. verbs of perception and cognition (see Bossong 1998, Haspelmath 2001, Verhoeven 2007 for a typo- 
logical perspective). One of the tendencies is for languages to change towards expressing the experiencer as subject rather than as object, something we'll see in this paper as well. Object experiencers, such as in (1a), are reanalyzed as subject experiencers, such as in (1b). This change is well-known from the Old English verb lician 'please' (Lightfoot 1979 and Allen 1995) which starts to be used in its modern meaning of like. Haspelmath (2001) shows that many languages spoken in Europe (his Standard Average European) use the subject experiencer strategy and the Atlas and Survey of Pidgin and Creole Linguistic Structure (Michaelis et al. 2013: 264-271) confirms that with verbs like and fear the subject experiencer is the most frequent pattern.

In this paper, I add (a) more detail on the changes in the reanalysis of the verb fear as a subject experiencer (sections 2 and 3), (b) a discussion of the constant renewal of object experiencers through external borrowing and internal change (section 4), and (c) data on the reanalysis of subject experiencers as agents (section 5). Thus, one aim is to show that the direction of change is from object to subject experiencer and that object experiencer verbs continue to be renewed. I also provide a framework for understanding changes in argument structure in terms of changes in the vP-shell and suggest a preliminary 'explanation'.

\section{Experiencer verbs in Old English: the reanalysis of object experiencers}

In this section, I first provide a partial list of the first attested use of certain psychverbs. How they first appear provides us insight into the changes they undergo. I then review the reanalysis of object experiencers as argued by van der Gaaf (1904), Jespersen (1909-1949), Lightfoot (1979), Fischer and van der Leek (1980), and Allen (1995).

\subsection{Psych-verbs}

Table 1 provides a partial list of Modern English psych-verbs as well as their first occurrence with the meaning they currently have, as gleaned from the OED. I am only including verbs with two DP arguments, not with clausal ones.

The reason for providing the list is that it shows several important developments in the history of English. (a) Many of the verbs that are now psych-verbs have become so recently. This indicates a lot of change. (b) A few subject experiencer verbs have remained stable, namely dread, hate, and love. (c) Some of the object experiencers have been reanalyzed as subject experiencers, e.g. like, fear, and loathe (see Table 2), but not the other way round. (d) Some of the renewals in the object experiencer verbs show causative markers (fright-en, in-furiate, embitter, and terr-ify). (e) Verbs that alternate, such as grieve and delight, have the object experiencer use as the earlier use and there may be an additional preposition or auxiliary for subject experiencers. This all shows a reanalysis from object experiencer to subject experiencer verb.

Table 2 summarizes the most obvious changes from object experiencer to subject experiencer. The table also shows there is overlap between the uses and I will 
Table 1. Alternating psych-verbs (this choice is based on Croft 1993: 56; Levin 1993: 188-93; Pesetsky 1995: 18; Talmy 2001: 99)

\begin{tabular}{llll}
\hline ObjExp & first occurrence & SubExp & first occurrence \\
\hline anger & 1200 & be angry & 1360 \\
vex & 1423 & detest & 1533 \\
annoy & 1300 & fume about & 1522 \\
disturb & 1230 & pity & 1475 \\
trouble & 1230 & regret & 1450 \\
hurt & 1526 & & \\
displease & 1377 & dislike & 1593 (briefly ObjExp) \\
distress & 1400 & despise & 1297 \\
irritate & 1531 & hate & OE \\
infuriate & 1667 & be furious about/at & 1855 \\
amuse & 1600 & love & OE \\
astonish & 1600 & marvel & 1380 (earlier ObjExp) \\
surprise & 1474 & be surprised & 1485 \\
please & 1350 & like & 1200 (earlier ObjExp) \\
delight & 1225 & delight in & 1450 \\
overjoy & 1382 & adore & 1300 \\
embitter & 1603 & resent & 1595 \\
cheer & 1430 & rejoice & 1390 \\
exhilarate & 1540 & admire & 1500 \\
worry & 1807 & worry with & 1671 \\
grieve & 1300 & grieve (over) & 1640 \\
bore & 1768 & be bored & 1768 \\
frighten & 1666 & fear & 1393 (earlier ObjExp) \\
scare & 1200 & be afraid & 1475 \\
terrify & 1536 & dread & OE \\
thrill & 1800 & relish & 1580 (earlier ObjExp) \\
vex & 1487 & & 1200 \\
\hline & & & \\
\hline
\end{tabular}

Table 2. Reanalysis of object experiencer as subject experiencer verbs

\begin{tabular}{lll}
\hline & ObjExp & SuExp \\
\hline fear: & OE-1480 & 1400 -present \\
like: & OE-1800 & 1200 -present \\
relish: & $1567-1794$ & 1580 -present \\
marvel: & $1380-1500$ & 1380 -present \\
loathe: & OE-1600 & 1200 -present \\
\hline
\end{tabular}




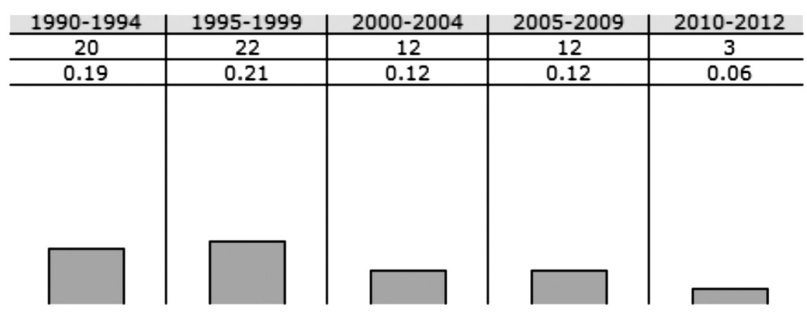

Figure 1. Decrease of pleases in COCA, absolute and per million.

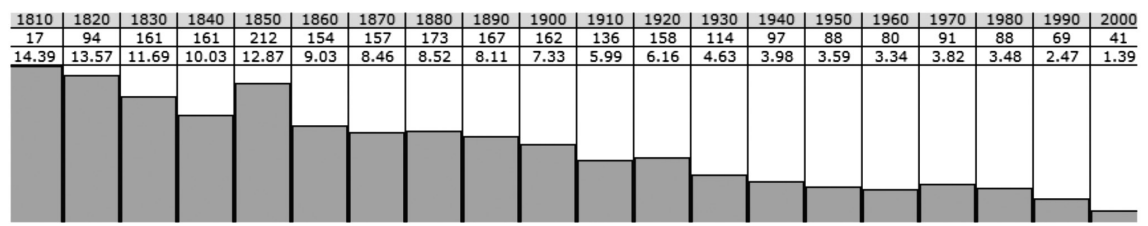

Figure 2. Decrease in use of pleases in $\mathrm{COHA}$, absolute and per million.

show in section 3 that, in certain transitionary texts, a verb may be used with an experiencer subject or experiencer object, as argued in Fischer and van der Leek (1980).

Another point of interest is that (object experiencer) verbs sometimes disappear. Table 1 shows that please is introduced in 1350 as an object experiencer verb. We might expect it to become a subject experiencer but that has not happened ${ }^{1}$. At the moment, however, there is a loss of this verb, as Figure 1 shows for the last 20 years of instances of the verb pleases in the Corpus of Contemporary American English (COCA) and Figure 2 for the last 200 years in Corpus of Historical American English (COHA). What these figures show is that, in the period between 1990 and 1999, there are 42 instances of ' $X$ pleases Y' but that the number decreases to 24 in the decade that follows. The same tendency is confirmed by looking at COHA which gives data for a 200 year period. The number provided under the absolute number is the occurrence per million words and here too the decline is obvious, from 14 per million in the period between 1810 and 1820 to a little more than 1 per million in the last decade of the $20^{\text {th }}$ century.

This loss of the use of certain object experiencer verbs may be due to the same reason as the reanalysis, namely that object experiencers are hard to acquire. I discuss this point more at the end of section 3.5.

1. Although please can be found with subject experiencers, as in (i), this use is rare.

(i) I please upon the creature which I... (EEBO, George Abbot 1651) 
Having provided some data to show that psych-verbs, in particular object experiencer ones, are quite unstable, in 2.2, I elaborate on some earlier thoughts on the reanalysis of object experiencer verbs. In the last section, I provide some reasons for their instability.

\subsection{From object to subject experiencer}

Psych-verbs, as earlier mentioned, express psychological states and involve an experiencer thematic role rather than an agent. This experiencer may act like the grammatical subject of the sentence but need not. In the latter case, the sentence may lack a referential subject and we use the term impersonal (Malchukov and Siewierska 2011). Impersonal verbs, psych-verbs included, have been the subject of discussion in much historical work, e.g. van der Gaaf (1904), Jespersen (1909-1949), Lightfoot (1979), Fischer and van der Leek (1980), Allen (1995), and Möhlig-Falke (2012) to name but a few.

Many have argued that the demise of impersonal verbs occurred due to case syncretism. However, Fischer and van der Leek (1980) argue that this cannot be so due to texts that have verbs with both meanings and Allen (1995) shows that the use of Experiencer objects continues well after the time that case was lost and that some verbs were introduced with an Experiencer Subject showing the construction was alive. The same continuation is obvious from work by Miura (2011) and others. The division in experiencer verbs that Allen (1995) adopts for Old English is the three-fold one of Elmer (1981). In that system, constructions, as in (4), with a dative experiencer and nominative theme or causer are labeled I, those, as in (5), with a nominative experiencer and genitive theme are referred to as II, and those with dative or accusative experiencer and genitive theme N. An example of the latter is given in (6).

(4) $P$ a bodan us faerdon Type I

the messengers us frightened

NOM-Theme DAT-Exp

'The messengers frightened us.' (OED, Ælfric Deut i. 28)

(5) He him ondrat his deap-es

Type II

he REFL fears his death-GEN

NOM-Exp GEN-Theme

'He fears his death.' (Ælfric Hom Skeat i, 12, 87)

(6) oððaet him wlatode paere gewilnunge Type $\mathrm{N}$

until him nauseated that desire

DAT/ACC-Exp GEN-Theme

'until he was nauseated of the desire.' (from Allen 1995: 70, Aelfric Homilies 21.89)

A list of the three types of verbs can be found in Table 3. Of these, ail, like, loathe, yearn, long, and shame are still in use but like and loathe have changed from 
Table 3. The three types of impersonal verbs, based on Elmer (1981: 69; 72) and Allen (1995: $71 ; 75)$ and additional sources

\begin{tabular}{lll}
\hline I & N & II \\
DAT Exp & DAT/AC Exp & NOM Exp \\
\hline eglian 'ail' & langian 'long for' & sceamian' 'shame' \\
(ge/of)hreowan 'distress' & lystan 'desire' & hreowan 'pity' \\
(ge)lician 'please' & ofhreowan 'pity' & reccan 'care' \\
lapian 'loathe' & ofpyncan 'regret' & giernan 'yearn' \\
losian 'lose' & sceamian 'cause/feel shame' & wilnian 'desire' \\
mislician 'displease' & (ge)spowan 'cause/feel success at' & behofian 'need' \\
oflician 'displease' & tweonian 'cause/feel doubt at' & \\
ofpyncan 'displease' & pyncan 'seem, think' & \\
pyncan 'seem, think' & wlatian 'nauseate/be nauseated' & \\
\hline
\end{tabular}

1. Tony Kim Dewey (p.c.) has evidence that Old English sceamian and hreowan are also of Type I but this is not important for my argument.

class I to II and long from N to II. Shame is now only used in passive participle form. Hate is not listed in this set but it is of type II, as (7) shows.

(7) Doð paem wel pe eow aer hatedon. do those well that you earlier hated 'Do well to those who formerly hated you.' (OED, c897 Ælfred Pastoral Care xxxiii. 222)

Note that types I and $\mathrm{N}$ overlap but are not similar. Type $\mathrm{N}$ is experiencer initial (Allen 1995: 104) and never has a dummy hit. This suggests the experiencer is a subject. Type I has the experiencer first when it is a pronoun but overall experiencers are "more likely to follow ... the Theme" (Allen 1995: 109).

In the next section, my focus will be on one verb and the various changes that affect it. I agree with Allen and others that the loss of case was not the reason behind this change because these verbs continue to be used long after the case was lost. Instead, I attribute it to a change in the set of light verbs due to a loss of the morphological causative.

\section{The verb faran/fear}

In this section, I provide data that show the change that the verb fear undergoes from Old to Middle to Modern English. I then look at some interesting characteristics of both the disappearing object experiencer construction and of the innovative subject experiencer one. 


\subsection{From 'frighten' to 'fear'}

From Old English until the late 14th century, the verb fceran means 'to frighten'; see (8).

(8) $P a$ bodan us faerdon =ExpObj

the messengers us frightened

'The messengers frightened us.' (OED, Ælfric Deut i. 28)

In the Middle English Dictionary, the entry for feren has both meanings 'to frighten' and 'to fear (respect)'. I provide all instances of these two meanings from the MED in (9) and (10) respectively. The second meaning is not attested before the end of the 14th century.

(9) a. He wile himm farenn 3iff he ma33.

'He wants to frighten him if he can.' (MED, c1200 Orm. Jun 1 675)

b. Alle these fereden vs [WB(2): maden vs aferd]. 'all these frightened us.' (MED, a1382 WBible(1) De 369(1) 2 Esd.6.9)

c. De lordes..bere whippes in hir hondes and so fered pe cherles, and droof hem away.

'.. and so frightened the churls and drove them away.'

(MED, a1387 Trev. Higd.(StJ-C H.1) 1.139)

d. Leue son, why hastou fered vs?

'Dear son why have you frightened us?' (MED, a1400 CursorTrin.12622)

e. Pe fend movep pes debletis to fere Cristene [men] fro treupe.

'The enemy moves these devils to frighten Christian men from the truth.' (MED, a1425 Wycl.Serm. Bod 788 2.328)

f. Thus he shal yow with his wordes fere.

'Thus, he'll frighten you with his words.' (MED, Chaucer TC 4.1483)

g. Many tymes haue I feryd pe wyth gret tempestys of wyndys.

'Many times have I frightened you with great wind storms.'

(MED, a1438 MKempe A (Add 61823) 51/24)

h. and pat pei feere hym fro vicis.

'and that they frightened him from vice.' (MED, c1443 Pecock Rule 320)

i. For to feare hym sir Dynadan seyde hit was sir Launcelot.

'Because, to frighten him, Sir Dynadan said it was Sir Lancelot.'

(MED, a1470 Malory Wks.Win-C 587/11)

j. In her hondys thei bare yrone speyruse, The fereful soule to feyre and enchase.

'In their hands, they had iron ... to frighten the fearful soul and to chase it.' (MED, a1475 VPhilibert Brog 2.1 p.33) 
(10) a. And that schold every wys man fere.

'And that should every wise man fear.'

(MED, a1393 Gower CA Frf 3 2.578)

b. Men feeren hem in al the toun Welmore than thei don of thonder.

'Men fear them in the entire town of Welmore (more) than they do thunder.' (MED, a1393 Gower CA Frf 3 3.454)

c. Fele ferde for pe freke(z), lest felle hym pe worre.

'Many feared for the man lest the worst happened to him.'

(MED, c1390 Gawain Nero A.10 1588)

d. Pou schalt nat fere For to be kyng of this regioun.

'You shall not be afraid to be king of this region.'

(MED, c1425 Lydg. TB Aug A.4 1.502)

e. Pan Vlixes..of his lyffeerd.

'Then Ulysses feared for his life.'

(MED, c1540/a1400 Destr.Troy Htrn 388 13842)

f. Alle that company fere I ryth nouth.

'All that group I fear not at all.'

(MED, a1475 Ludus C.Vsp D.8 369/394)

g. I fere me pat I shuld stond in drede.

'I fear that I shall stand in dread.'

(MED, a1500 Play Sacr. Dub 652 218)

A few points are worth noting: (a) the causative paraphrase in another version of (9b) and this is not unusual, (b) the mention of a result in (9c), (9e), and (9h) and an instrument in (9f) and (9g), and (c) the use of a reflexive in (10b) and (10g). I'll discuss all three of these details now, starting with the causative.

\subsection{Object experiencers are causatives}

In section 1, it was mentioned that object experiencers involve causatives structures and that they are marked with an overt causative morpheme in some languages. In this section, I show that this is true in Old English too.

A verb with the meaning 'to frighten' has an inherent causative meaning. According to the OED, the Old English verb fóran 'fear' has its origin in a causative form *fôrjan, a weak verb 'to terrify' that derives from the noun fôer. Garcia Garcia's (2012) list of more or less productive causatives in Old English includes several psych-verbs and they are all object experiencer verbs: $a$-hwoenan 'vex, afflict', gremman 'enrage', a-bylgan 'anger', swencan 'harrass', a-prytan 'weary', wagan 'vex', and wyrdan 'annoy'.

Older Germanic languages and Old English have verbalizing $-j /-i$ affixes that add a causer to the argument set. In Gothic, these are clearly visible, as shown in Table 4. Note that the -an suffix adds the infinitive ending, not important for the present paper. 
Table 4. Causatives in Gothic (based on van Hamel 1931: 186-187; Prokosch 1939: 153; and Ottosson 2009: 35)

\begin{tabular}{ll}
\hline \multicolumn{1}{c}{ Verb } & \multicolumn{1}{c}{ Verb } \\
\hline urreisan 'arise' & urrais-j-an 'to make arise' \\
sliupan 'walk silently' & afslaup-j-an 'to make slip away' \\
brinnan 'burn' intr. & gabrann-j-an 'to burn something' \\
sitan 'sit' & sat-j-an 'to put' \\
drigkan 'drink' & drak-j-an 'make drink' \\
ligan 'lie' & lag-j-an 'lay' \\
-redan 'prepare' & rod-j-an 'make think' \\
Noun & Verb \\
stains 'stone' & stain-j-an 'to stone' \\
doms 'judgment' & dom-j-an 'to judge' \\
wens 'hope' & wen-j-an 'to hope' \\
Adjective & Verb \\
laus 'loose' & laus-j-an 'to loosen' \\
hails 'whole' & hail-j-an 'to heal' \\
blinds 'blind' & gablind-j-an 'to blind' \\
\hline
\end{tabular}

Table 5. Causatives in Old English, from Ottoson (2009)

\begin{tabular}{ll}
\hline drēopan 'drop' & drīepan 'moisten', \\
\hline belgan 'be/become angry' & äbielgan 'irritate', \\
\hline hweorfan 'turn/go/die' & hwierfan 'turn/destroy ', \\
\hline meltan 'melt, burn up, be digested' & mieltan 'melt/purge', \\
\hline sincan 'sink' & sencan 'sink, submerge/drown', \\
\hline springan 'jump/burst forth/spread' & sprengan 'scatter/burst', \\
\hline nesan 'escape from/be saved' & nerian 'save/protect', \\
\hline sigan 'sink/fall/move' & sæægan 'cause to sink/fell/destroy', \\
\hline scrincan 'shrink/wither' & screncan 'cause to shrink', \\
\hline feallan 'fall/flow/die' & fiellan 'fell/defeat/destroy'. \\
\hline
\end{tabular}

By the time of Old English, phonological processes have made the affix mostly invisible, as shown in Table 5, and all that's left is an effect on the stem vowel (as is still the case in Modern English intransitive fall, sit, and lie and causative fell, set, and lay). 
Lass (1994: 166) writes that, by Old English, the function of $-i$ as causativizer is visible only in a small group of verbs, in line with Visser (1963) and Bosworth and Toller (1898). I agree with Ottosson (2009: 51), who concludes that even though the $j$-causatives were less transparent in Old English, this formation may still have been somewhat productive. After the evidence is lost more and more, verbs become increasingly labile in English (from 80 in Old English to 800 in Modern English; see McMillion 2006 and van Gelderen 2011).

Thus, by the end of Old English, the causative morphology is no longer transparent and analytic forms get to be used, e.g. the light verb do, as in (11). This use is present in Old English already.

(11) a. De barn sco dide drinc o pat wel. the child she made drink of that well 'She made the child drink from the well.' (Cursor Mundi, Cotton 3071)

b. She dud pe childe drynke of Pe welle (idem, Trinity)

c. Đis deuel ... doð men hungren \& hauen drist. 'This devil ... makes men hunger and have thirst.' (MED, a1250 Bestiary (Arun 292) 428)

As the causative suffix disappears, there are a number of replacements, e.g. the -en suffix in Middle English (12) on verbs like durken 'darken', the zero morpheme on verbs like blak 'blacken' in (12), the late Middle English causative en-prefix (13a-c), and the early Modern suffixes -ify, as in beautify and neatify, -ize, as in advertize, and -ate, as in accumulate.

(12) De aier gun durken and to blak.

'The air began to darken and to blacken.' (OED, Cursor Mundi, Vesp. 24414)

(13) a. [These things] doe ... exceedingly possesse and englad our hearts. (OED, 1604 Supplic. Certaine Masse-priests §1)

b. That Vaiano Which engoldens and empurples in the grounds there of my Redi. (OED 1825 Hunt Redi's Bacchus in Poet.Wks. (1860) 386)

c. A womans looke his hart enfeares.

'A woman's look makes his heart fearful.' (OED, 1608 T. Hudson tr. G. de S. Du Bartas Ivdithv. 70 in J. Sylvester Deuine Weekes \& Wks.)

The prefix en- is extremely popular for a while but many die out, e.g. enfear in (13c) but also enwiden, enweaken, ensoak, enstuff, and enquicken (s.v. en- in the OED).

In 3.2, I have discussed the demise of the morphological causative in Old English and the renewal of the causative through light verbs and prefixes borrowed from French. I'll come back to these changes in 3.5. 


\subsection{The result and instrument}

Now let's turn to the goal or instrument being very frequent in (9) above. Other such examples are (14), and also occur with particles, as in (15).

(14) Hou anticrist \& his clerkis feren trewe prestis fro prechynge of cristis gospel. 'How the antichrist and his clerks frighten true priests from preaching Christ's gospel.' (OEDc1380 Wyclif Works Speculum de Anti christo)

(15) a. Fere away the euyll bestes.

'Frighten the evil animals away.'

(OED, 1504 Atkinson tr. Ful Treat. Imytacyon Cryste (Pynson) iii. xxvii)

b. If there were nothing else to feare them away from this play. (OED, 1577 Northbrooke Spiritus est Vicarius Christi: Treat. Dicing 93)

Having a goal or instrument accompany a causative, such as fear, reinforces the change of state typical of a causative. I will come back to this point in my analysis in 3.5 .

\subsection{Reflexives causing ambiguity}

There are early cases with ambiguity, as in (16), depending on whether the postverbal pronoun is seen as a reflexive or not. Thus, it is not clear whether (16a) means 'I frighten myself that ...' or 'I fear that ...' These ambiguous sentences occur mainly when the cause/subject matter is clausal and sentence-final, as in (16), but also without these, as in (17).

(16) a. I fere me ye haue made a rodde for your self.

'I fear/frightened myself you have made a rod for yourself.'

(OED s.v. rod1485 Malory's Morte Darthur (Caxton) v. ii. sig. hviiiv

b. I feared me alwayes that it wolde be so.

(OED, 1530 Palsgrave, Lesclarcissement 547/2)

c. I feare me he is slaine. (OED, a1593 Marlowe Edward II (1594) sig. E3v)

(17) a. All to son, my brother, I fere me, for yow.

(Helsinki Corpus, Mankind, 162)

b. "A, dowtyr," seyd owyr Lord, "fere pe nowt, I take non hede what a man hath ben, but take hede what he wyl ben".

(Helsinki Corpus, Margery Kempe, chap 21)

c. 'feare you not,' quoth these stout wemen.

(Helsinki Corpus, Thomas Harman, 71)

The same text may have a causative with object experiencer as well as a reflexive with subject experiencer, as (18a) and (18b) show respectively. 
(18) a. Thou wenyste that the syght of tho honged knyghtes shulde feare me? 'You thought that the sight of those hanged knights should frighten me?' (MED, a1470 Malory Wks.Win-C 322/17)

b. Sir Palomydes was the more wayker and sorer was hurte and more he loste of his blood than sir Lame roke..'Sir,' seyd sir Dynadan ... 'I feare me that sir Palomydes may nat yett travayle.'

(MED, a1470 Malory Wks.Win-C 606/17)

By the end of the 16th century, the experiencer object with fear is lost, as in (19).

(19) He that but feares the thing hee would not know, Hath ... knowledge from others eies, That what he feard is chanced. (1600 Shakespeare Henry IV.2 i. i. 87)

I'll now turn to a possible account for the loss of the experiencer object.

\subsection{The loss of the causative and a reanalysis of little $v$}

I will now turn to the analysis of experiencer verbs and the reason for the change from object to subject experiencer. In short, the loss of the morphological causative, as outlined in 3.2, makes the construction less transparent and, in accordance with work by Schein (1993) and Kratzer (1996), I argue that Themes are parts of the lexical entry of the verb and that this makes experiencer objects difficult to process and that the thematic hierarchy is in conflict with an animacy hierarchy.

First, I'll provide an analysis of the changes. Much work in recent years (e.g. Ramchand 2008), assumes three layers in the traditional VP-area, a high little $\mathrm{v}$ that can be aspectually marked as an eventive by an initiator bringing about a change of state (either intentionally or not) or as a stative by an experiencer, as in (20); the middle layer which houses the measured or affected argument, as in (21); and the lowest layer with a result or goal argument, as in (22).

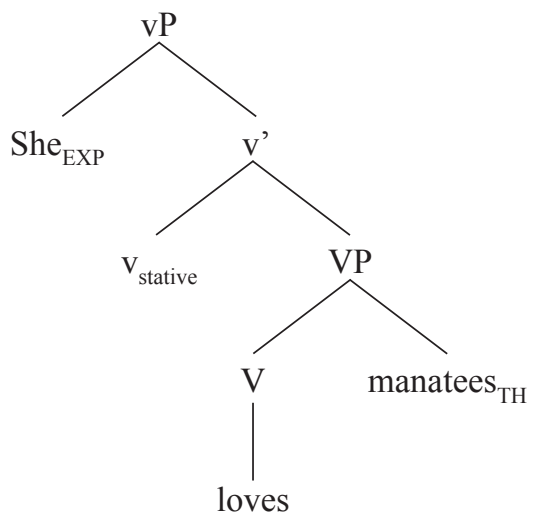


(21)

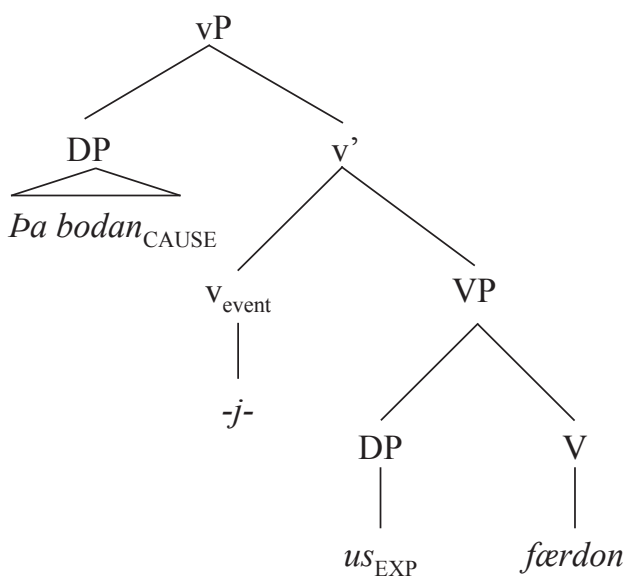

(22)

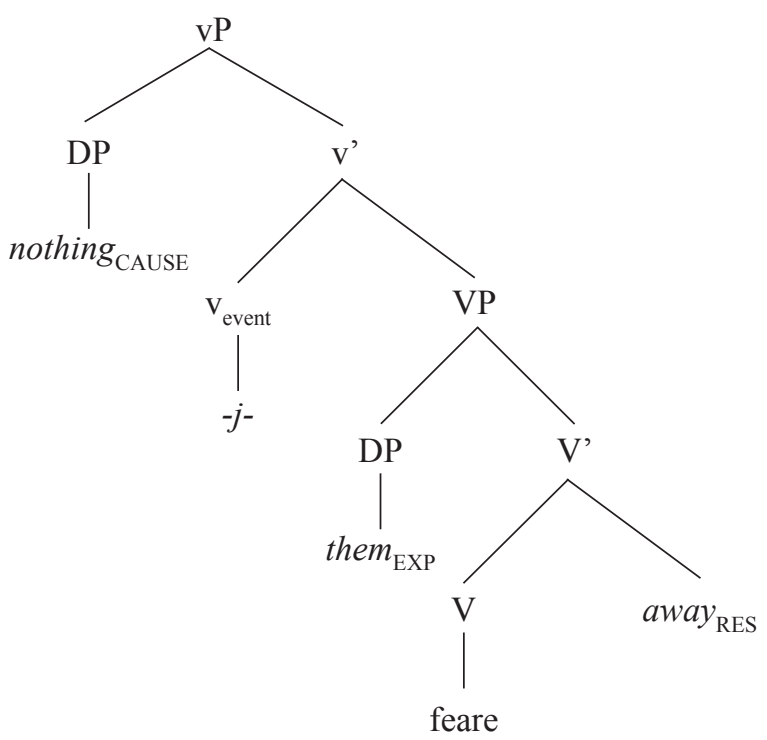

After the morphological causative weakens during Old English, other light verbs occupy that space, e.g. do, make, put, -ify, -ate, -en, and en-, as shown in (11), (12), and (13). There is also an increased use of the instrument in (14) and result in (15) that helps to emphasize the change of state typical of the causative that is losing its marking. The light verbs, however, are highly various as well, as e.g. Clancy (2010) has shown. Thus, do could mean 'give, make, let, put' in one early Middle English text. This multi-functionality points to a situation where the contents of $\mathrm{v}$ are unclear and reanalysis can occur.

Cross-linguistically, reflexives are often affixed to the verb and bring about changes in valency and aspect. For instance, in Romance, reflexives mark incho- 
ativity and what were earlier reflexives in Scandinavian are now used as passives. I will therefore argue that reflexives are ambiguous between phrase- and head-status. The reflexive experiencer in (16b) can be analyzed as in (23) where feared moves to little $\mathrm{v}$, now occupied by the reflexive. The $\mathrm{v}$ is ambiguous between stative and eventive aspect, and the new meaning triggered is the former.

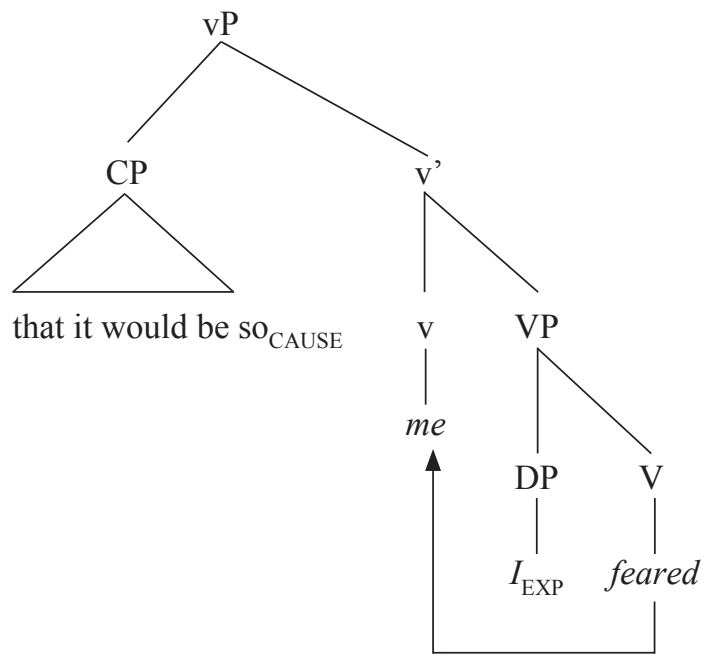

Sentences, such as (17b), have a similarly ambiguous tree, as shown in (24).

(24) a.

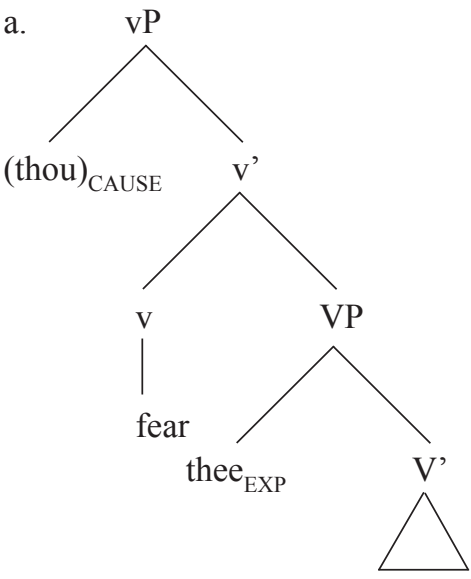

b.

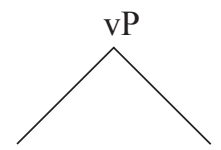

(thou) $)_{\text {EXP }}$

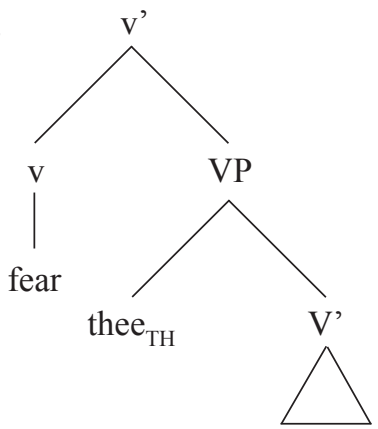

The latter stage enables a reanalysis from the causal 'frighten' to 'fear', with a structure as in (25). 


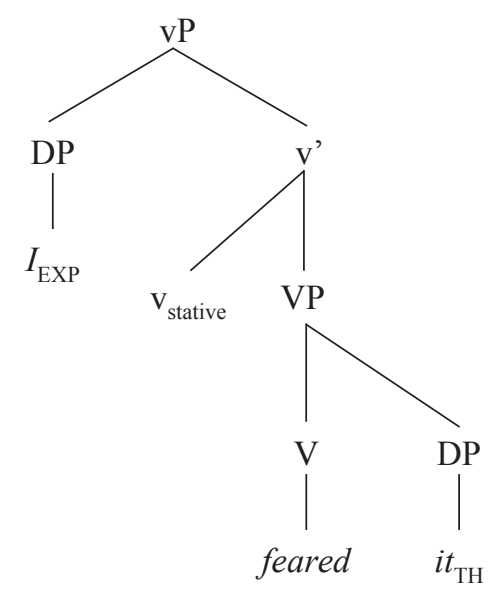

Having described the changes in the argument structure, possibly started by the loss of the causative, the question arises why this happens. I will suggest two reasons.

First, Ryan (2012) shows that the Theme theta-role appears in data from first language acquisition, that is before the Agent or any other theta-role. This fits with Schein (1993) and Kratzer (1996) who argue that the Theme cannot be introduced via a light verb but is relevant to the meaning of the lexical verb. This makes Themes into natural grammatical objects and Experiencer objects possibly hard to learn. This then might cause their reanalysis as subject Experiencers.

Secondly, the reason for the renewal by certain causative verbs is possibly prelinguistic in Jackendoff's (2002: 245) sense. When animacy hierarchies are incongruous with thematic hierarchies, the child will try to reconcile the two. Thus, with causatives whose highest argument is an inanimate and whose lowest argument is an animate, e.g. 'a ball stunned me', the Theme is 'upgraded' to an Experiencer. If we assume an animacy hierarchy is important pre-linguistically, semantically, and pragmatically, the thematic hierarchy of (2) is the grammaticalization of this, i.e. an exaptation of the semantic animacy hierarchy to syntax ${ }^{2}$. Once in a while, there is conflict between the two and then the latter may prevail.

\section{Renewal of experiencer object verbs}

Interestingly, it turns out that many of the current Object Experiencer verbs are loans, e.g. anger is a loan from Old Norse. Another source for renewal is through internal change and, in some cases, this use is quite recent, e.g. worry has the meaning of 'kill' in Old English and only appears with the meaning of 'to vex' in the 19th century. This use remains in British English where 'dogs can worry sheep' by biting their throats. Table 6 provides a few of the sources of renewal. I will focus on internal change. 
Table 6. Some examples of renewal of object experiencer verbs

\begin{tabular}{lll}
\hline anger, scare & 1200 & Old Norse \\
astonish & 1375 & unclear \\
frighten & 1666 & internal change \\
grieve & 1330 & French \\
please & 1350 & Anglo-Norman \\
irritate & 1531 & Latin \\
stun & 1700 & internal change \\
worry & 1807 & internal change \\
\hline
\end{tabular}

Haspelmath (2001), based partly on Cole et al (1980), suggests two changes: in the Experiencer Object and changes in verbal meaning. (a) Experiencer Objects first acquire subject behavior. (b) Verbs change from concrete to abstract, e.g. fascinate and stun originally mean 'to bewitch' and 'to deprive of consciousness or of power of motion by a blow', respectively. I'll focus on (b).

In the pre-Experiencer Object meaning, these verbs have Agent or Causer subjects, as (26) and (27) show, but they have developed experiential meanings, as shown in (28) and (29). The argument structure of the two verbs has changed from Agent (or Causer) and Theme to Theme (or Cause) and Experiencer.

(26) a. They kill it [a fish] by first stunning it with a knock with a mallet. (OED 1662 J. Davies tr. A. Olearius Voy \& Trav. Ambassadors 165)

b. The ball, which had been nearly spent before it struck him, had stunned instead of killing him. (OED, 1837 Irving Capt. Bonneville I. 271)

(27) Why doe Witches and old women, fascinate and bewitch children? (OED 1621 R. Burton Anat Melancholy i. ii. iii. ii. 127)

(28) a. You shall sometimes see him gather a Crowd round him ... and stun the People with a senseless Story of an Injury that is done him. (OED, 1714 E. Budgell tr. Theophrastus Moral Characters vi. 22)

b. I thought I knew a lot about entomophagy around the world, but this book stunned me. (http://www.menzelphoto.com/books/meb.php)

(29) Purple eggs ... fascinated her (http://live.psu.edu/story/52214)

Other such verbs are worry, thrill, astonish, and grieve. The verb worry meant 'to kill by strangling/compressing the throat' in Old and Middle English, as in (30), with an Agent and Theme and is reanalyzed as a verb with an Agent and an object experiencer. The verb thrill meant 'to pierce', as in (31), and is similarly later changed into an object experiencer. 
(30) Haral ... threwe hym to the grounde and had wyried hym with his hondes, 'Harald threw him to the ground and strangled him with his handes.'

(OED, 1387 Trevisa tr. R. Higden Polychron. VII. 534)

(31) \& scharp lance pat thrilled Ihesu side.

'and the sharp lance that pierced Jesus' side.'

(OED, c1330 Mannyng Chron. 1810: 30)

The verb astonish has an earlier variant aston(i)e, as in (32a), of which the OED says "perhaps the ending is due to Old French past participle estoné" but which Morris (1866: 286) says is from Old English stunian 'to strike' and (32b) seems to confirm that. There are early instances that are already ambiguous, as given in (32c).

(32) a. Hou it ssolde ous ssende and astonie.

'How it should destroy and stun us' (OED, 1340, Ayenbite (1866) 126)

b. The one smote the king upon the head, the other astonished his shoulder. 'The one struck the kong on the head; the other struck his shoulder.' (OED, 1600, Holland tr. Livy Rom. Hist. xlii. xv. 1124)

c. Des wordis astonyeden hem.

'These words astonished them.'

(OED, c1375, Wycliffite Serm. in Sel. Wks. 1871: II. 113)

The verb grieve was borrowed from French with the meaning of 'to burden, harass', as (33) shows, and as an experiencer object use appears in (34).

(33) a. Clerkes ... he greuede manion.

'Clergymen... he harassed many a one.'

(OED, 1297 Gloucester's Chron. 11815)

b. Moche thei greved the hethen peple with alle theire power.

'Much they harassed the heathens with all their power.'

(OED, a1500 Merlin (1899) xii. 186)

(34) Our fredom that day for euer toke pe leue, For Harald it went away, his falshed did vs greue.

'That day, our freedom forever took leave, because of Harald it went away. His falsehood grieved us.'

(OED, c1330 Mannyng Chron. (1810) 71)

The changes are very gradual. For instance, uses of worry and grieve with the meanings of 'strangle' and 'do bodily harm', respectively, occur till the 19th century, as in (35) and (36), although figurative uses occur early on, e.g. (37). 
(35) She bit me ... She worried me like a tigress.

(OED, 1847 Brontë Jane Eyre II v 124)

(36) The graceful foliage storms may reave, The noble stem they cannot grieve. (OED, 1810 Scott Lady of Lake ii. 57)

(37) hou faste pe woluys of helle wirien cristen soulis.

'how firmly the wolves of hell worry Christian souls.'

(OED, c1380 Wyclif Wks. 1880: 24)

In short, object experiencers are indeed reanalyzed as subject experiencers and new object experiencers arise through the reanalysis of the Theme as an Experiencer. This occurs because a physically affected object can be seen as mentally affected too, as explained in Ruwet (1972), Bouchard (1995), Arad (1998).

\section{From experiencer to agent}

The last change to look at is one that is currently attracting some attention, namely that from stative to non-stative and from subject experiencer to agent, as in (38) to (41).

(38) the skiers are loving this -- about a foot of snow for you. (COCA Spoken 2009)

(39) I am liking private life a lot right now. (COCA Spoken 2009)

(40) I've been going around, and I am liking what I see in the classrooms (COCA Spoken 2002)

(41) So how's he liking his new single status? (COCA Magazine 2012)

Anecdotally, this construction is blamed on a fast food add and on facebook where people are urged to 'like' certain stories, as in (42).

(42) I don't know that an anti-Gingrich or Romney or Obama group on Facebook that has a lot of people liking it is going to have a big impact on the campaign, but this is how people organize themselves these days online. (COCA Spoken 2012)

The COCA corpus has 1157 instances of liking as a verb, with most instances in fiction. Many of these are complements to auxiliaries such as keep on, stop, and end up, as in (43), and are still stative.

(43) she ended up liking it more than maybe she would have thought.

(COCA Spoken 2012) 
Looking at the auxiliary be followed by the verb liking, there is a steady set of such examples, e.g. six instances in 2011 in the spoken portion of COCA, namely those given in (44).

(44) a. Exactly. I want -- I 'm liking Geoffrey Rush. (COCA NBC Today)

b. That's how much women of a certain age, like us, are liking it. So let's watch. (COCA NBC_Today)

c. He's having some breakfast. RUSS-MITCHELL: Ah, he's liking that. (COCA CBS_Early)

d. If the Democrats are liking Medi-scare and nine percent unemployment, one percent economic expansion, and huge debt ... (COCA Fox_Baier).

e. WILLIAMS: I'm liking it. Thanks very much. (COCA NBC RockCenter).

f. I whip my hair back and forth. You know and so he's liking it (COCA CNN Morgan).

There are 13 similar examples of be with loving, given in (45).

(45) a. The Steelers are loving it. (COCA NBC Today)

b. So we recommend, lately we've been loving broccoli rabe, which is higher in iron and calcium than regular broccoli ... (COCA NBC Today)

c. Yes. I think we're loving it. I mean all eyes are on London at the moment and, you ... (COCA CBS Early)

d. Yeah. It's only in New Orleans. I'm loving it. With meals like this, it's hard to imagine anyone being able (COCA CBS Early)

e. Oh, I'm loving this. (LAUGHTER) (COCA STOSSEL)

f. I was loving it. I mean, I was sort of in a weird place in my ... (COCA ABC 20/20)

g. and asking them to wrestle, you know. They're loving this. (COCA CNN Behar)

h. - actually, we -this is our first week (unintelligible), and I'm loving every minute of it. (COCA NPR ATC)

i. No, I -but keep going, I'm loving it. CLARKSON: Oh. OK, it's coming up, the chorus, (COCA NBC Today)

j. Carolina, sunny sky, seventy-three with the light breeze. Oh, you're loving it. Why? High pressure here ... (COCA CBS Early)

k. I hope you like cranberry. Good. ... Yeah, I'm loving this right now. (COCA CBS Early)

1. Even now you're loving every second of that, aren't you? Be honest. (COCA CNN Morgan)

$\mathrm{m}$. and just towards the end -it had gone very well and everyone was loving it. (COCA CNN Morgan) 
Apart from like and love, are other subject experiencer verbs undergoing this change? Fear and know are, as (46) and (47) show.

(46) a. I've been fearing the answers. (COCA Fiction 2007)

b. Wall Street is fearing a bloodbath (COCA Magazine 2007)

(47) And so everybody in town was knowing that this was happening (COCA Spoken 2009).

Frequently used diagnostics to determine if arguments are Agents or Experiencers are the use of deliberately with Agents, personally with Experiencers, and -er with Agents. Neither deliberately nor the -er occur with fear yet which means the reanalysis isn't complete. Structurally, we could argue that when Experiencers are reanalyzed as Agents, the change from (48a) to (48b) happens. There is a 'promotion' of the Experiencer due to the loss of the stative character of fear.

(48) a.

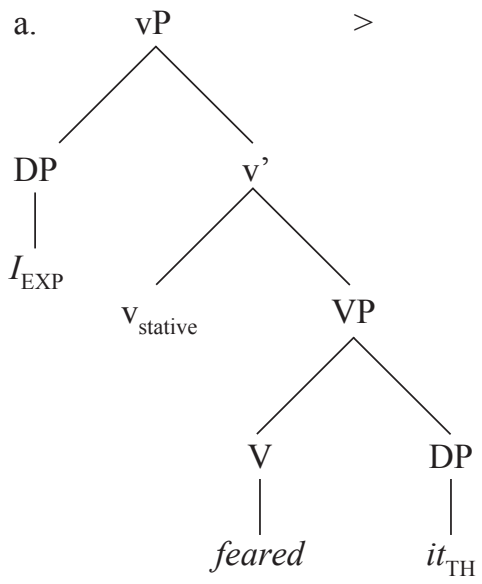

b.

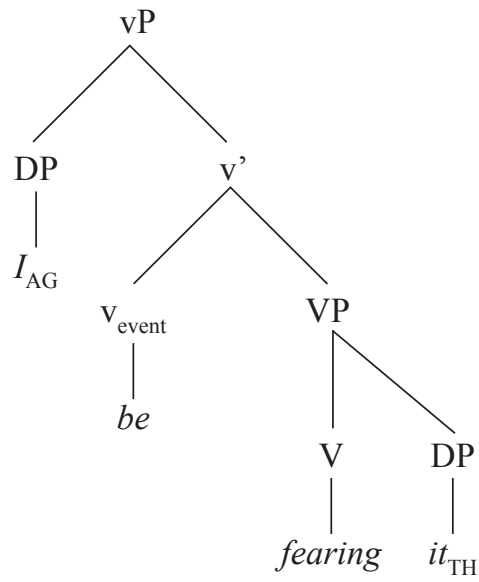

The change discussed in this section, i.e. the introduction of sentences such as (38), involves a reanalysis of the light verb from stative to non-stative aspect. With animate specifiers of vP, such reanalysis is always possible.

\section{Conclusion}

In this paper, I have looked at some changes in the meaning and argument structure of verbs and have attributed those to changes in the repertoire of light verbs. In sections 2 and 3, I discuss the well-known reanalysis of object experiencers as subject experiencers. I focus on the changes of the verb foran, which changes from meaning 'to frighten' (object experiencer) to 'to fear' (subject experiencer) and identify some factors that give us insight into the reasons behind the reanalysis, e.g. the frequent strengthening of the old meaning by a causative light verb and 
the use of a reflexive with the new meaning. These additions provide evidence of a change in the light verb inventory.

In section 4, I examine the sources of renewal for object experiencers. Some are borrowed while others arise through a reanalysis of a class of verbs where the highest theta-role is ambiguous between agent and causer. The theme is seen as experiencer and a new object experiencer arises. A last change, discussed in section 5 , is the change of subject experiencer psych-verb to regular transitive. I suggest that language-external reasons play a role.

I have described three major changes in the argument structure of verbs in terms of light verbs. In section 3, I have also accounted for why these changes might have taken place. There are two different reasons for this preference for reanalyzing experiencer objects as subjects. One is based on the special status of the Theme and a second is based on discrepancies regarding animacy that occur as a result of grammaticalization.

\section{References}

Allen, Cynthia (1995). Case marking and reanalysis. Oxford: Oxford University Press. Arad, Maya (1998). VP Structure and the syntax-lexicon interface. University College London, doctoral dissertation.

Baker, Mark (1988). Incorporation. Chicago: Chicago University Press.

Belletti, Adriana; Rizzi, Luigi (1988). «Psych-Verbs and Theta-Theory». Natural Language and Linguistic Theory 6: 291-352.

Bossong, Georg (1998). «Le marquage de l'expérient dans les langues d'Europe». In: Feuillet, Jack (ed.). Actance et Valence dans les Langues de l'Europe. Berlin: Mouton de Gruyter, pp. 259-294.

Bosworth, Joseph; Toller, Thomas Northcote (1898). An Anglo-Saxon Dictionary. Oxford: Clarendon Press.

Bouchard, Denis (1995). The Semantics of Syntax. Chicago: University of Chicago Press.

Clancy, Steven (2010). The Chain of Being. Amsterdam: John Benjamins.

COCA. The Corpus of Contemporary American English, a 450 million word corpus from between 1990-2010. http://www.americancorpus.org/

COHA. The Corpus of Historical American English, a corpus from between 1800-2010. http://www.americancorpus.org/

Cole, Peter; Harbert, Wayne; Hermon, Gabriella; Sridhar, S. N. (1980). «The acquisition of subjecthood». Language 56.4: 719-743.

Croft, William (1993). «Case marking and the semantics of mental verbs». In: Pustejovsky, James (ed.). Semantics and the Lexicon. Dordrecht: Kluwer.

DOE Dictionary of Old English. http://www.doe.utoronto.ca.

EEBO, Early English Books Online. http://eebo.chadwyck.com/home.

Elmer, Willy (1981). Diachronic Grammar: The history of Old and Middle English subjectless constructions. Tübingen: Niemeyer.

Fischer, Olga; van der Leek, Frederike (1983). «The demise of the Old English impersonal construction». Journal of Linguistics 19: 337-368. 
Folli, Raffaella; Harley, Heidi (2005). «Consuming results: Flavors of little- $v »$. In: Kempchimsky, Paula; Slabakova, Roumyana (eds). Aspectual Enquiries Dordrecht: Kluwer, 1-25.

Gaaf, Willem van der 1904. The transition from the impersonal to the personal construction in Middle English. Heidelberg: Winter.

García García, Luisa (2012). «Morphological causatives in Old English: the quest for a vanishing formation». Transactions of the Philological Society 110.1: 122-148.

Gelderen, Elly van (2011). «Valency Changes in the History of English». Journal of Historical Linguistics 1.1: 106-143.

Gelderen, Elly van (2013). Clause Structure. Cambridge: Cambridge University Press.

Haspelmath, Martin (2001). «Non-Canonical Marking of Core Arguments in European Languages». In: Aikhenvald, Alexandra Y.; Dixon, ,Robert M. W.; Onishi, Masayuki (eds). Non-Canonical Marking of Subjects and Objects. Amsterdam: John Benjamins, 53-83.

Helsinki Corpus, see http://ota.ahds.ac.uk/desc/1477.

Jackendoff, Ray (2002). Foundations of language. Oxford: Oxford University Press.

Jespersen, Otto (1909-1949). Modern English Grammar. London: George Allen and Unwin.

Kratzer, Angelica (1996). «Severing the External Argument from the Verb». In Rooryck, Johan; Zaring, Laurie (eds). Phrase Structure and the Lexicon. Dordrecht: Kluwer, 109-137

Lass, Roger. (1994). Old English. Cambridge: Cambridge University Press.

Levin, Beth (1993). English Verb Classes and Alternations: A Preliminary Investigation. Chicago: University of Chicago Press.

Lightfoot, David (1979). Principles of Diachronic Syntax. Cambridge: Cambridge University Press.

McMillion, Allan (2006). Labile Verbs in English. University of Stockholm, doctoral dissertation.

Michaelis, Susanne; Maurer, Philippe; Haspelmath, Martin; Huber, Magnus (eds) (2013). The Atlas and Survey of Pidgin and Creole Languages, 4 volumes. Oxford: Oxford University Press.

Malchukov, Andrej; Siewierska, Anna (2011). Impersonal Constructions. Amsterdam: John Benjamins.

Middle English Dictionary. http://quod.lib.umich.edu/m/med/.

Miura, Ayumi (2011). Middle English Verbs of Emotion and Impersonal Constructions. University of Manchester, doctoral dissertation.

Morris, Richard (1866). Dan Michel's Ayenbite of Inwyt. London: Trübner \& Co.

Möhlig-Falke, Ruth (2012). The Early English Impersonal Construction. Oxford: Oxford University Press.

Ottosson, Kjartan (2009). The anticausative and related categories in the old Germanic languages. ms. University of Oslo. [published In: Josephson, Folke; Söhrman, Ingmar (eds.) (2013). Diachronic and Typological Perspectives on Verbs. Amsterdam: John Benjamins, 329-382.]

Oxford English Dictionary (OED) 1933. Oxford: Oxford University Press.

OED online. http://www.oed.com/.

Pesetsky, David (1995). Zero Syntax. Cambridge, Mass.: MIT Press. 
Prokosch, Eduard. (1939). A comparative Germanic grammar. Philadelphia: University of Pennsylvania and Linguistic society of America.

Pylkkänen, Lisa (2008). Introducing Arguments. Cambridge, Mass.: MIT Press.

Ruwet, Nicolas (1972). Theorie syntaxique et syntaxe du français. Paris: Editions du Seuil.

Ryan, John (2012). The Genesis of Argument Structure: Observations of a Child's Early Speech Production in Spanish. Saarbrucken: Lambert Academic Publications.

Schein, Barry (1993). Plurals and Events. Cambridge, Mass.: MIT Press.

Talmy, Leonard (2001). Toward a Cognitive Semantics II. Cambridge, Mass.: MIT Press.

Van Hamel, Anton Gerard. (1931). Gotisch handboek. Vol. 3. Haarlem: H. D. Tjeenk Willink \& Zoon.

Verhoeven, Elisabeth (2007). Experiential Constructions in Yucatec Maya. Amsterdam: John Benjamins.

Visser, Frederik T. (1963). An Historical Syntax of the English Grammar, Vol I. Leiden: Brill. 